\title{
Distribution of Heavy Metals in Sediments at the Commercial and Fishing Ports in Samoa
}

\author{
T. Imo, F. Latū, V. Vaurasi, J. Yoshida, P. Amosa, and M. A. Sheikh
}

\begin{abstract}
Contamination of heavy metals in coral reefs and coastal areas is a serious ecotoxicological and environmental problem due to direct runoff from anthropogenic wastes, commercial vessels and discharge from industrial effluents which may accumulate in the suspended particulate matter and settle on the bottom sediment. Surface sediment samples were collected from Samoa's commercial and fishing port and studied for the concentration and distribution of heavy metals. Two heavy metals $(\mathrm{Cu}, \mathrm{Pb})$ were detected from each port with some concentration below the permissible maximum concentration of environment quality standard set by the World Health Organization.
\end{abstract}

Index Terms-Sediments, heavy metals, distribution, Samoa.

\section{INTRODUCTION}

Samoa has undergone tremendous commercial growth and development over the last 10-15 years. The coastal waters along Apia's shoreline are now utilized for commercial and fishing activities. The Apia port is one of the busiest international shipping lanes in the Pacific region. The increasing marine traffic in the Apia port poses an increasing threat of marine pollution. The term heavy metal refers to any metallic chemical element that has a relatively high density and is toxic or poisonous at low concentrations. Examples of heavy metals that are harmful to humans include mercury, lead, and arsenic. Chronic exposure to these metals can have serious health consequences. Humans are exposed to heavy metals through inhalation of air pollutants, consumption of contaminated drinking water, exposure to contaminated soils or industrial waste, or consumption of contaminated food. Food sources such as vegetables, grains, fruits, fish and shellfish can become contaminated by accumulating metals from surrounding soil and water. Heavy metal exposure causes serious health effects, including reduced growth and development, cancer, organ damage, nervous system damage, and in extreme cases, death. Exposure to some metals, such as mercury and lead, may also cause

Manuscript received February 7, 2014; revised May 3, 2014. This work was supported by the National University of Samoa's Research Ethics Committee.

T. Imo, F. Latū, V. Vaurasi, and J. Yoshida are with the National University of Samoa, Faculty of Science, Samoa (e-mail: t.imo@nus.edu.ws, f.latu@nus.edu.ws, j.leungwai@nus.edu.ws, v.vaurasi@nus.edu.ws, j.yoshida@nus.edu.ws).

P. Amosa is with the Chemistry Department, Faculty of Science, University of Otago, NZ (e-mail: saloi@chemistry.otago.ac.nz, pamosa@chemistry.otago.ac.nz).

M. A. Sheikh is with the Centre for Graduate Studies and Research, State University of Zanzibar, Zanzibar, Tanzania (e-mail: m.sheikh@suza.ac.tz). development of autoimmunity, in which a person's immune system attacks its own cells. This can lead to joint diseases such as rheumatoid arthritis, and diseases of the kidneys, circulatory system, and nervous system. Biofouling occurs when organisms, such as bacteria, algae and invertebrates especially barnacles and mussels are attached to submerged structures such as vessels in the Marine environment [1]-[3]. Most rivers in the world flowing through the populated areas are highly vulnerable to heavy metal pollution due to urbanization and industrialization. Anthropogenic impacts geogenic processes deteriorate sediment and water quality. Therefore, studies on the determination of the degree of anthropogenic impact on river sediment have been especially relevant over the last decades [4]-[9]. Many approaches have been applied in order to assess the severity of sediment contamination and to understand the natural and anthropogenic inputs in the river system. The metal assessment indices namely enrichment factor, geo-accumulation index, pollution load index and sediment quality guidelines were often used to screen the potential for contaminants within sediment. Metals are particularly toxic to the sensitive, rapidly developing systems of fetuses, infants, and young children. Some metals, such as lead and mercury, easily cross the placenta and damage the fetal brain. Childhood exposure to some metals can result in learning difficulties, memory impairment, damage to the nervous system, and behavioral problems such as aggressiveness and hyperactivity. At higher doses, heavy metals can cause irreversible brain damage. Children may receive higher doses of metals from food than adults, since they consume more food for their body weight than adults. The biofouling of the underwater area of vessels has serious impact on the operational costs of shipping, due to increased fuel consumption. To prevent biofouling, the submerged structures such as vessels are typically painted with a coating containing heavy metals, such as tin and copper, which kills these fouling organisms on contact [10]. Leaching of heavy metals from boats and ships coated with antifouling paints, resulted in potential toxic concentrations in the water column, sediments and tissues of marine organisms have been documented in developed countries [11]. Concentrations were especially high in areas of high shipping or boating activity and very serious biological impacts were inevitable in the most contaminated areas. A previous study on heavy metals in some marine organisms has been well documented in Samoa [12]. However, no systematic studies have been carried out on the distribution of heavy metals in commercial and fishing ports in Samoa. Hence, this study investigates the distribution of heavy metals in sediments of commercial and fishing ports and adjacent environments around Samoa. 


\section{Methodology}

\section{A. Study Site}

This study was conducted at the fishing port (Savalalo) $\left(13.83^{\circ} \mathrm{S}, \quad 171.77^{\circ} \mathrm{W}\right)$ and Mulifanua wharf $\left(13.8^{\circ} \mathrm{S}\right.$, $\left.172.02^{\circ} \mathrm{W}\right)$.

\section{B. Sampling and Preparation}

Samples were collected within the months of August-October 2013 from 5 sites at Mulifanua Wharf (MW1-MW5) and 5 sites at the Fishing port (FW1-FW5) as shown in Fig. 1. Sediment samples $(3-5 \mathrm{~cm})$ were collected and placed in a polyethylene plastic bag and kept in an ice box. Samples were oven dried to a constant dry weight at $80^{\circ} \mathrm{C}$ and sieved through a $63 \mu \mathrm{m}$ stainless steel sieve.

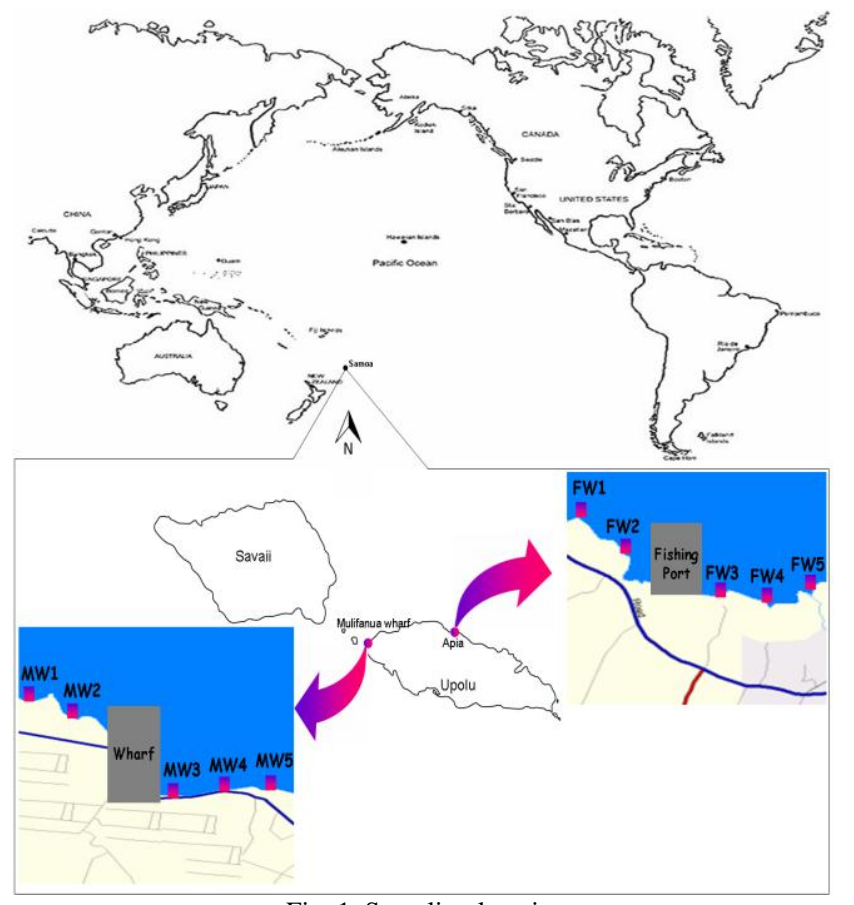

Fig. 1. Sampling locations.

\section{Chemical Analysis}

About $0.5 \mathrm{~g}$ of dried homogenised sample was placed in a $50 \mathrm{~mL}$ Digitube. The $<65 \mu \mathrm{m}$ fraction was used for the evaluation of sediment physicochemical parameters namely $\mathrm{pH}$, conductivity, organic matter and bicarbonates of calcium. Sediment's $\mathrm{pH}$ was measured in a suspension of 25 $\mathrm{mL}$ de-ionized water to $5 \mathrm{~g}$ of sediment after shaking for 2 hrs. Conductivity was evaluated from the suspension prepared by adding $50 \mathrm{~mL}$ de-ionized water to $5 \mathrm{~g}$ of sediment and shaken for $30 \mathrm{~min}$. The organic matter was determined by ignition at $600^{\circ} \mathrm{C}$ for $6 \mathrm{hrs}$ in a muffle furnace. The percentage of loss on ignition was considered as Total Organic Matter (TOM). The blank samples were all prepared in duplicates by adding $2 \mathrm{~mL}$ of deionized water to each tube. The spiked samples were prepared by adding $200 \mu \mathrm{L}$ of 500 $\mathrm{mg} / \mathrm{L}$ trace metals Intermediate Standards (contains Fe, Mn, $\mathrm{Cu}, \mathrm{Cd}, \mathrm{Pb}, \mathrm{Zn}$ ) to a sample replicate. A $2.5 \mathrm{~mL}$ of concentrated nitric acid was added to each digestion vessel and left overnight to pre-digest. The samples were placed in the digestion block and heated to $80^{\circ} \mathrm{C}$ for 60 minutes. Samples were again left overnight to settle out any solid material. The resultant mixture was made up to $50 \mathrm{~mL}$ with distilled water. Heavy metal $(\mathrm{Cu}, \mathrm{Pb})$ analysis was achieved by flame atomic absorption spectrometry.

TABLE I: PHYSICOCHEMICAL PARAMETERS OF SEDIMENTS FROM DIFFERENT STATIONS

\begin{tabular}{cccc}
\hline \hline Sites & TOM $(\%)$ & Mean $\mathrm{pH}$ & Mean CE $(\mu \mathrm{S} / \mathrm{cm})$ \\
\hline MW1 & 4.17 & 8.63 & 505 \\
MW2 & 4.64 & 8.17 & 499 \\
MW3 & 2.69 & 8.29 & 345 \\
MW4 & 4.49 & 7.99 & 372 \\
MW5 & 3.03 & 8.03 & 500 \\
FW1 & 3.13 & 6.79 & 986 \\
FW2 & 2.77 & 7.63 & 449 \\
FW3 & 3.90 & 7.94 & 387 \\
FW4 & 2.54 & 8.54 & 813 \\
FW5 & 3.50 & 7.14 & 293 \\
\hline \hline
\end{tabular}

\section{RESUlts AND Discussion}

The sediments collected at the Mulifanua wharf and the Fishing port shows an insignificant variation in $\mathrm{pH}$ values that range from $7.99-8.63$ and $6.79-8.54$. Conductivity (EC) shows higher values in all samples (Table I). This increase in conductivity may be attributed to the high content of soluble salts in sediments [13], [14].The relatively high content of TOM is mainly related to the high organic matter flux to sediments due to direct runoff from anthropogenic activities near their location.

The heavy metals $(\mathrm{Cu}, \mathrm{Pb})$ were detected in all sediment samples from the commercial and fishing ports in Samoa as shown in Tables II and III. In the commercial port, the concentration of heavy metals in August ranged from (1.01-3.59 mg/g (Cu)), (1.23-2.56 mg/g (Pb), September $(1.01-3.71 \mathrm{mg} / \mathrm{g}(\mathrm{Cu})),(1.32-2.73 \mathrm{mg} / \mathrm{g}(\mathrm{Pb}))$ and October $(1.10-3.82 \mathrm{mg} / \mathrm{g}(\mathrm{Cu})),(1.32-2.82 \mathrm{mg} / \mathrm{g}(\mathrm{Pb}))$. The highest concentration of $\mathrm{Cu}$ and $\mathrm{Pb}$ was found at sites MW2, MW1 respectively. The mean concentration of metals from the samples collected at the commercial port is in the order of $\mathrm{Pb}>\mathrm{Cu}$. Mulifanua wharf is the closest wharf and convenient for commuters between Upolu and Savaii Island, thus the increased traffic of ferries daily. The heavy metals detected in the Mulifanua wharf indicated that the boating activities contributed a significant amount of $\mathrm{Pb}$ and $\mathrm{Cu}$ into sediments.

TABLE II: CONCENTRATION OF METALS (mg/g) IN SELECTED SAMPLES (COMMERCIAL PORT)

\begin{tabular}{ccc}
\hline \hline Sites & $\mathrm{Cu}($ mean \pm stdev $)$ & $\mathrm{Pb}($ mean \pm stdev $)$ \\
\hline MW1 & $2.21 \pm 0.07$ & $0.13 \pm 0.13$ \\
MW2 & $3.71 \pm 0.12$ & $0.10 \pm 0.01$ \\
MW3 & $1.09 \pm 0.13$ & $0.09 \pm 0.01$ \\
\hline \hline
\end{tabular}

TABLE III: CONCENTRATION OF METALs (mg/g) IN SELECTED SAMPLES (FISHING PORT)

\begin{tabular}{ccc}
\hline \hline Sites & $\mathrm{Cu}($ mean \pm stdev $)$ & $\mathrm{Pb}($ mean \pm stdev $)$ \\
\hline FW1 & $2.25 \pm 0.12$ & $1.32 \pm 0.36$ \\
FW2 & $3.41 \pm 0.17$ & $1.80 \pm 0.20$ \\
FW3 & 1.24 & $1.85 \pm 0.09$ \\
\hline \hline
\end{tabular}

In the fishing port, the concentration of heavy metals in August ranges from $(0.97-2.03 \mathrm{mg} / \mathrm{g}(\mathrm{Cu}),(0.97-2.03 \mathrm{mg} / \mathrm{g}$ $(\mathrm{Pb})$, September (1.01-3.26 mg/g $(\mathrm{Cu}),(1.15-1.94 \mathrm{mg} / \mathrm{g}(\mathrm{Pb})$, 
October $(0.79-3.59 \mathrm{mg} / \mathrm{g}(\mathrm{Cu}),(1.23-1.85 \mathrm{mg} / \mathrm{g}(\mathrm{Pb})$. The highest concentration of $\mathrm{Cu}$ detected was found at site FW2 while the highest concentration of $\mathrm{Pb}$ was found at site FW3. The mean concentration of metals in the samples is similar to that in the commercial port. The levels of some of these heavy metals are below the WHO regulatory permissible limits of $(0.03 \mathrm{mg} / \mathrm{g} \mathrm{Cu}),(0.02 \mathrm{mg} / \mathrm{g} \mathrm{Pb})$ set by the WHO [1].

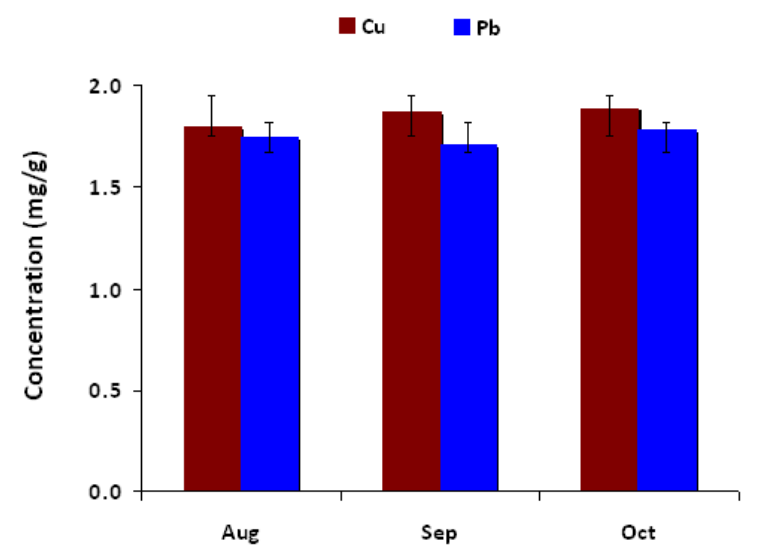

Fig. 2. Overall mean concentration of heavy metals in the samples collected at the Mulifanua wharf.

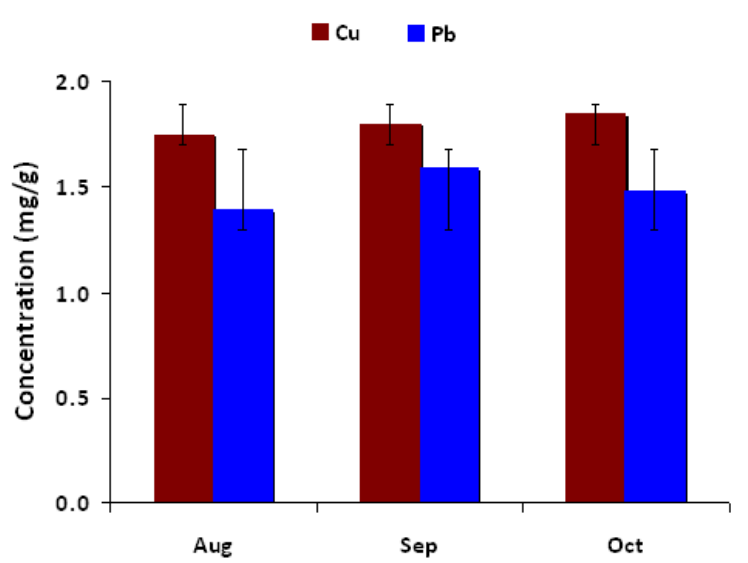

Fig. 3. Overall mean concentration of heavy metals in the samples collected at the fishing port.

TABLE IV: HEAVy METAL CONCENTRATION (mg/g) IN THE SEDIMENT FROM THE DIFFERENT REGIONS OF THE WORLD

\begin{tabular}{|c|c|c|c|}
\hline Rivers & $\mathrm{Cu}$ & $\mathrm{Pb}$ & Reference \\
\hline This study & $0.97-3.82$ & $1.23-2.82$ & \\
\hline Cochin estuary, India & 53.15 & 71.28 & $\begin{array}{l}\text { Balachandran et al. } \\
(2005)^{[16]}\end{array}$ \\
\hline Jurujuba sound, Brazil & 51.0 & 61.0 & $\begin{array}{l}\text { Baptista Neto } \text { et al. } \\
(2000)^{[17]}\end{array}$ \\
\hline $\begin{array}{l}\text { Tolo harbour, Hong } \\
\text { Kong }\end{array}$ & 84.0 & 144.0 & $\begin{array}{l}\text { Owen and Sandhu, } \\
(2000)^{[18]}\end{array}$ \\
\hline Izmit Bay, Turkey & 67.6 & 102.0 & Pekey $(2006)^{[19]}$ \\
\hline $\begin{array}{l}\text { Koahsiung Harbour, } \\
\text { Taiwan }\end{array}$ & $5-946$ & $9.5-470$ & $\begin{array}{l}\text { Chen et al. } \\
(2004)^{[20]}\end{array}$ \\
\hline $\begin{array}{l}\text { Eastern Harbour, } \\
\text { Egypt }\end{array}$ & 14.09 & - & $\begin{array}{l}\text { Abdallah and } \\
\text { Abdallah } \\
(2007)^{[21]}\end{array}$ \\
\hline River Ganga, India & 0.09 & - & $\begin{array}{l}\text { Singh et al. } \\
(2012)^{[22]}\end{array}$ \\
\hline $\begin{array}{l}\text { Mudflat of Salinas de } \\
\text { San Pedro Lagoon, } \\
\text { California, USA }\end{array}$ & $0.085-0.47$ & $0.05-0.38$ & $\begin{array}{l}\text { Mohammad H.R et } \\
\text { al. }(2013)^{[23]}\end{array}$ \\
\hline
\end{tabular}

Fig. 2 and Fig. 3 present the overall mean concentrations $(\mathrm{mg} / \mathrm{g})$ of the metals in the sediment samples collected from the Mulifanua wharf and fishing port during the sampling months. Samples collected from the Mulifanua wharf revealed significantly higher levels of copper and lead than the samples collected at the fishing port. This could be due to the increased traffic of ferries between the two islands as most businesses and locals equipped for the festive seasons towards the end of the year. Metal concentrations from the sampling locations were compared with values reported from different regions of the world (Table IV) and the levels were comparable to concentration detected in sediments from the different regions of the world.

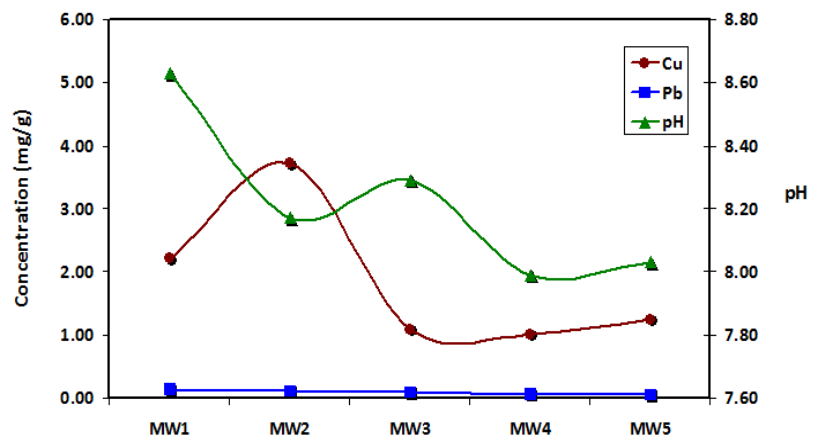

Fig. 4. $\mathrm{pH}$ of heavy metals in the samples collected at the Mulifanua wharf.

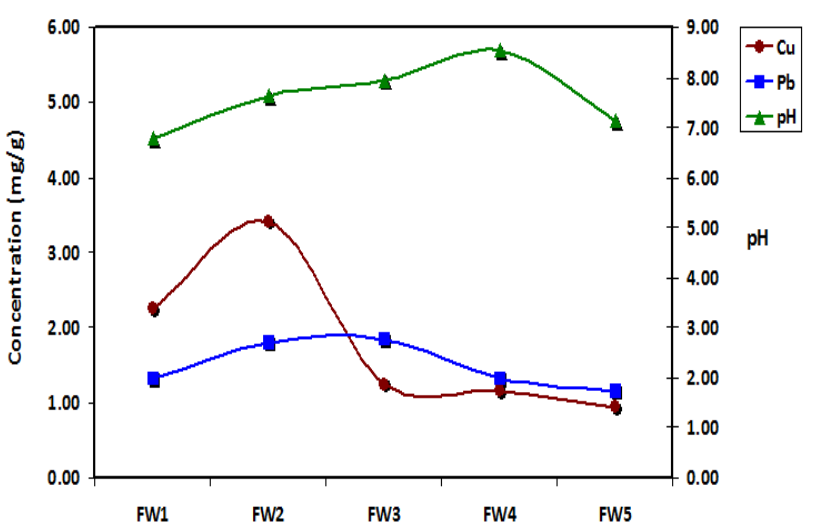

Fig. 5. $\mathrm{pH}$ of heavy metals in the samples collected at the fishing port.

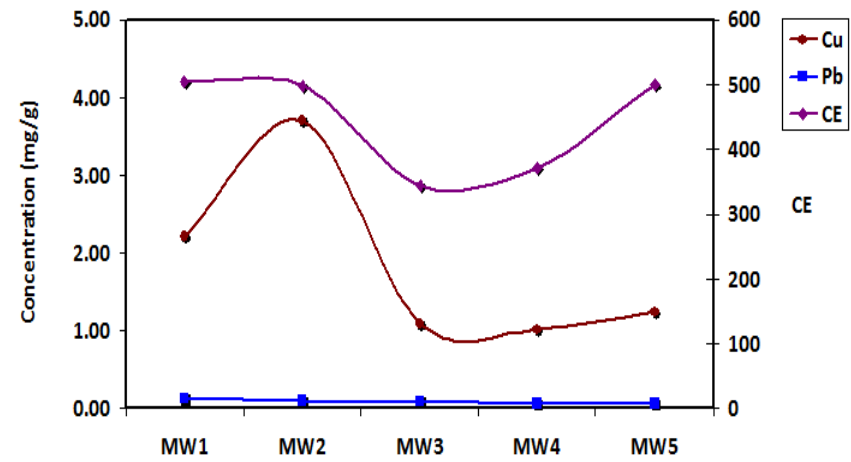

Fig. 6. Conductivity of heavy metals in the samples collected at the Mulifanua wharf.

Sediments may play a considerable role in the remobilization of trace metals from bottom sediments into the water body under suitable conditions and consequently, fish ingestions and bio-accumulations. The release of heavy metals from sediments may not only result from re-suspension of particulate matters, but also through the activities of micro-organisms within the sediments and at 
sediment-water interface, resulting in bio-transformation to more volatile or soluble forms [15]. Fig. 4 and Fig. 5 show the correlation between heavy metals collected from each sites and the $\mathrm{pH}$ values. The alkalinity of the samples is probably due to the effect of direct runoff from anthropogenic activities from near locations. While other sites, the alkalinity is relatively less than the other sites. Fig. 6 and Fig. 7 show the relationship between the conductivity and heavy metals concentration from each site. Some sites show an increase in conductivity compared to other sites.

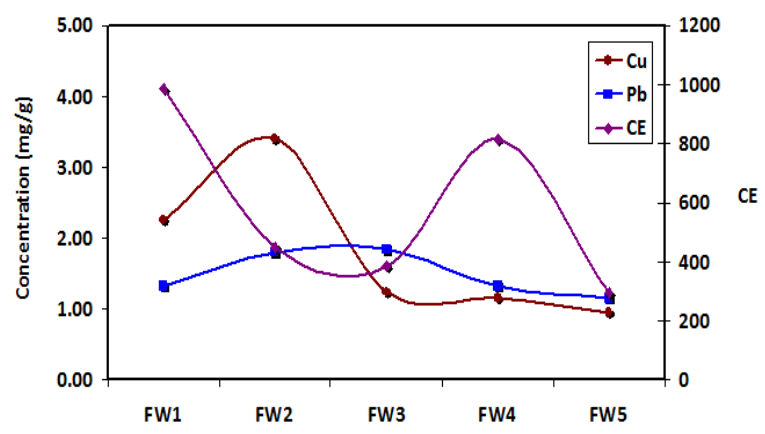

Fig. 7. Conductivity of heavy metals in the samples collected at the fishing port.

\section{CONCLUSION}

In Samoa, the information on the ecotoxicological impact of heavy metals on sediments is limited. This study presents baseline data on the distribution of heavy metals in sediments collected around the commercial and fishing ports in Samoa. The sediments recorded high levels of heavy metals $(\mathrm{Cu}, \mathrm{Pb})$ in all sampling locations within the sampling months which could be due to boating activities. Great efforts and cooperation between different authorities are needed to protect the coastal and coral reef ecosystems from pollution and reduce environmental risk. This can be achieved by treatment of the residential and sewage discharge. Regular evaluation of pollutants in the coastal and coral reef ecosystems is also very important.The results obtained from this study advocate for further studies regarding emerging threats of heavy metals on the vital marine resources which have significant importance to the livelihood of coastal societies, particularly Small Island States including Samoa.

\section{ACKNOWLEDGMENT}

We are grateful to the University Research Ethics Committee (UREC) of the National University of Samoa, for the financial assistance which enabled this research to be done. We would also like to thank our colleagues in the Department of Science for their assistance in sample collection.

\section{REFERENCES}

[1] WHO, Guidelines for Drinking Water Quality, 4th ed, Geneva, 2011, p. 451.

[2] M. A. Sheikh, N. M. Noah, K. Tsuha, and T. Oomori, "Occurrence of tributyltin compounds and characteristics of heavy metals in marine environments in East Africa," Int. J. Environ. Sci. Tech., vol. 4, no. 1, pp. 49-59, 2007.

[3] R. Company, H. Felıcia, A. Serafim, A. J. Almeida, M. Biscoito, and M. J. Bebianno, "Metal concentrations and metallothionein-like protein levels in deep-sea fishes captured near hydrothermal vents in the
Mid-Atlantic Ridge off Azores," Deep-Sea Research I, vol. 57, pp 893-908, 2010.

[4] C. P. Priju and A. C. Narayana, "Heavy and trace metals in Vembanad lake sediments," Int. J. Environ. Res., vol. 1, no. 4, 280-289, 2007.

[5] N. Bidhendi, T. Nasrabadi, H. Hoveidi et al., "Influence of copper mine on surface water quality," Int. J. Environ. Sci. Tech., vol. 4, no. 1, pp. 85-91, 2007.

[6] S. Dixit and S. Tiwari, "Impact assessment of heavy metal pollution of shahpura lake Bhopal India," Int. J. Environ. Res., vol. 2, no. 1, pp. 37-42, 2008.

[7] T. Venugopal, L. Giridharan, and M. Jayaprakash. "Characterization and risk assessment studies of bed sediments of river Adyar-an application of speciation study," Int. J. Environ. Res., vol. 3, no. 4, pp. 581-598, 2009.

[8] A. Biati, F. Moattar, A. R. Karbassi, and A. H. Hassani, "Role of saline water in removal of heavy elements from industrial wastewaters," Int. J. Environ. Res., vol. 4, no. 1, pp. 177-182, 2010.

[9] M. Jayaprakash, B. Urban, P. M. Velmurugan, and S. Srinivasalu, "Accumulation of total trace metals due to rapid urbanization in microtidal zone of Pallikaranai marsh, South of Chennai, India," Environ. Monit. Assess., vol. 170, pp. 609-629, 2010.

[10] J. Burger and M. Gochfeld, "Heavy metals in commercial fish in New Jersey," Environmental Research, vol. 9, pp. 403-412, 2005.

[11] B. Amin, A. Ismail, A. Arshad, and M. Kamarudin, "Distribution and Speciation of Heavy Metals $(\mathrm{Cd}, \mathrm{Cu}$ and $\mathrm{Ni})$ in coastal sediments of Dumai Sumatera, Indonesia," Journal of Coastal Development, vol. 10 , no. 2, pp. 125-141, 2007.

[12] C. Vieux and J. Kinch, Monitoring Program for Fagaloa and Uafato Bays Samoa: Final Report, 2010.

[13] G. G. Gilmour, T. H. Tuttle, J. C. Means, "Tin methylation in sulphide bearing sediment in marine and estuarine geochemisty," in Marine and Estuarine Geochemistry, A. C. Siglo and A. Hatton, Eds. Chelsea, Michigan: Lewis publishers, pp. 239-258, 1985.

[14] M. J. Mohammad and N. Mazahreh, "Changes in soil fertility parameters in response to irrigation of forage crops with secondary treated wastewater," Soil Sci. Plant. Anal., vol. 34, no. 9-10, pp. 1281-1294, 2003.

[15] A. O. Barakat, A. Mostafa, T. L. Wade, S. T. Sweet et al., "Assessment of persistent organochlorine pollutants in sediments from Lake Manzala," Egypt, Mar Pollut Bull, 2012.

[16] K. K. Balachandran, C. M. L. Raj, M. Nair, T. Joseph, P. Sheeba, and P. Venugopal, "Heavy metal accumulation in a flow restricted, tropical estuary," Estuarine, Coastal and Shelf Science, vol. 65, pp. 361-370, 2005.

[17] J. A. B. Neto, B. J. Smith, and J. J. McAllister, "Heavy metal concentrations in surface sediments in a nearshore environment of Jurujuba Sound, Brazil," Environmental Pollution, vol. 109, pp. 1-9, 2000.

[18] R. B. Owen and N. Sandhu, "Heavy metal accumulation and anthropogenic impacts on Tolo Harbour, Hong Kong," Marine Pollution Bulletin, vol. 40, pp. 174-180, 2000.

[19] H. Pekey, "The distribution and sources of Heavy metals in Izmit Bay surface sediments affected by a polluted stream," Marine Pollution Bulletin, vol. 52, pp. 1197-1208, 2006.

[20] Z. Chen, Y. Saito, Y. Kanai, T. Wei, L. Li, H. Yao, and Z. Wang, "Low concentration of Heavy metals in the Yangtze estuarine sediments, China: a diluting setting," Estuarine, Coastal and Shelf Science, vol 60, pp. 91-100, 2004.

[21] M. A. M. Abdallah and A. M. Abdallah, "Biomonitoring Study of Heavy Metals in Biota and Sediments in the Southern Coast of Mediterranean Sea, Egypt," Environmental Monitoring and Assessment, 2007.

[22] L. Singh, S. K. Choudhary, and P. K. Singh, "Status of heavy metal concentration in water and sediment of River Ganga at selected sites in the middle Ganga Plain," Int. J. Res. Chem Env., vol. 2, no. 4, pp. 236-243, 2012.

[23] H. R. B. Mohammad, T. Vanessa, D. Sonya, L. Teresa, T. Mathew, D. D. Dimitri, "The geochemistry of heavy metals in the mudflat of Salinas de San Pedro Lagoon, California, USA," Journal of Environmental Protection, pp. 12-25, 2013.

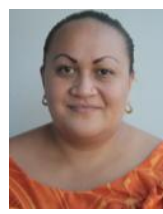

Taema Imo is an associate professor in environmental science in the Faculty of Science of the National University of Samoa. Her research is geared towards environmental and marine pollution, management and toxicology. She is a lecturer in the Faculty of Science. 


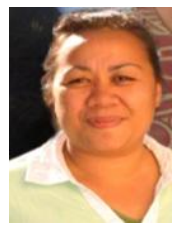

Patila Amosa is a final year PhD student in the Department of Chemistry of the University of Otago, New Zealand. Her research interests are in the areas of marine pollution and oceanography.

Varea Vaurasi is a final year undergraduate in the School of Agriculture of the University of the South Pacific. Her research interests are in the areas of agrochemicals and

pollution.

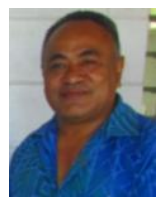

Faainuseiamalie Latū is the head of the Science Department of the Faculty of Science. He has been intensively involved in various environmental projects with the Ministry of Natural Environment in Samoa and also with regional organization such as SPREP and international universities.

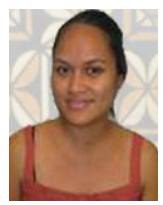

